\title{
FINANSINIŲ TECHNOLOGIJŲ ITAKOS KOMERCINIŲ BANKŲ PELNINGUMO RODIKLIAMS TYRIMAS
}

\author{
Indrè LAPINSKAITE், Reda KVEDARYTE் \\ Vilniaus Gedimino technikos universitetas, Verslo vadybos fakultetas, \\ Finansu inžinerijos katedra, Saulètekio al. 11, LT-10223, Vilnius, Lietuva \\ "El.paštas reda.kvedaryte@stud.vgtu.lt
}

\begin{abstract}
Santrauka. Tyrime siekiama įvertinti finansinių technologijų įtaką komercinio banko pelningumo rodikliams. Straipsnyje analizuojama mokslinė literatūra, aprašomi naudojami tyrimo metodai, atliekama panelinių duomenų regresinè analizè (XLSTAT programa) siekiant ịvertinti ịtaką. Atliekant tyrimą analizuojama Lietuvoje veikiančių komercinių bankų naudojamos finansinès technologijos (mokejjimo kortelès, bankomatai, mokèjimo kortelių skaitytuvai, elektroninè bankininkystè) ir turto grąžos pelningumo rodiklis (ROA) bei nuosavo kapitalo grąžos rodiklis (ROE) laikotarpyje nuo $2014 \mathrm{~m}$. iki $2018 \mathrm{~m}$. Atlikus tyrimą atmetamos iškeltos hipotezès, kad finansinès technologijos daro itaką komercinių banku pelningumo rodikliams, kadangi atlikto tyrimo rezultatai neparodè reikšmingos finansinių technologijų įtakos komercinių bankų pelningumo rodikliams. Tyrimo rezultatai gali įspèti komercinius bankus dèl investicijų atsiperkamumo diegiant finansines technologijas. Tačiau svarbu atkreipti dėmesi i apribojimus, kadangi šio tyrimo rezultatai remiasi tik Lietuvoje veikiančiu komercinių bankų duomenimis, o dèl mažos duomenų imties rezultatai gali būti netikslūs.
\end{abstract}

Reikšminiai žodžiai: komercinis bankas, finansinès technologijos, turto grąžos rodiklis (ROA), nuosavo kapitalo grąžos rodiklis (ROE), pelningumas.

\section{Ivadas}

Tyrimo aktualumas. Šiuo metu technologijos labai sparčiai tobulëja, keičia pasauli. Finansinių paslaugų sektoriuje technologijų naudojimas tapo neatsiejama kasdienybe. Komerciniai bankai savo veikloje, siekdami pagreitinti procesus ir supaprastinti paslaugų teikimą klientams, nuolatos diegia naujas finansines technologijas ir jas tobulina. Finansinių technologijų naudojimas komerciniams bankas ne tik teikia naudą, tačiau tai yra didelès investicijos ir sąnaudos siekiant neatsilikti nuo rinkos konkurentų. Mokslininikai nagrinèdami komercinių bankų naudojamas finansines technologijas daugiausiai demesio skyria konkrečiai vienai technologijai, tačiau nėra plačiai analizuojama keleto ịdiegtų finansinių technologijų įtaka banko pelninigumui.

Tyrimo problema. Kaip finansinès technologijos naudojamos komerciniuose bankuose daro įtaką komercinio banko pelningumui?

Tyrimo objektas. Komercinių bankų pelningumas.

Tyrimo tikslas. Ištirti finansinių technologijų daromą ịtaką komercinių bankų pelningumui.

Tyrimo uždaviniai:

1. Išanalizuoti finansinių technologijų panaudojimo ir pelningumo rodiklių komerciniuose bankuose teorinius aspektus.

2. Pateikti metodus ir modelius galinčius ịvertinti finansinių technologijų įtaką komercinių bankų pelningumo rodikliams.

3. İvertinti finansines technologijas darančias įtaką komercinių bankų pelningumo rodikliams.

Metodai: literatūros analizè, statistinių duomenų rinkimas ir apdorojimas, finansinių pelno rodiklių metodai, panelinių duomenų regresija.

Tyrimo apribojimai. Dèl duomenų trūkumo, trumpo tiriamojo laikotarpio ir mažos duomenų imties, tyrimo rezultatai gali būti netikslūs. Taip pat, tyrime naudojama tik trijų Lietuvoje veikiančių komercinių bankų duomeys, o tai susiaurina tyrimo rezultatu pritaikomumą ir tikslumą. 


\section{Finansinès technologijos naudojamos komerciniuose bankuose ir pelningumo vertinimas}

Finansinių paslaugų sektorius labai sparčiai tobulèja ir vystosi, prisitaiko prie greito žmonių gyvenimo tempo bei vis didesnio informacijos kiekio. Klientams yra pasiūloma daugiau galimybių norimas paslaugas gauti reikiamu metu, pigiau ir kokybiškiau. Šis finansų rinkos tobulëjimas vyksta dèl finansinių technologiju (fintech) panaudojimo.

Finansinès technologijos yra technologiju pritaikymas finansuose, tai žodžių finansinès ir technologijos junginys. Tačiau žodis fintech neturi konkretaus apibrěžimo. İvairūs autoriai analizuodami fintech skirtingai apibrěžia šią sąvoką. Thakor (2020), Gai et al. (2018), Dhar ir Stein (2017) teigia, kad tai yra finansiniu paslaugų teikejų technologiju naudojimas teikiant naujas ir patobulintas finansines paslaugas, kiti autoriai autoriai pavyzdžiui Saksonova ir Kuzmina-Merlino (2017), Puschmann (2017) apibrèžia, kad tai finansinių paslaugų teikejjai, kurie dar tik kuriasi ir savo veikloje remiasi technologijų naujovèmis, kad suteiktų geresnes finansines paslaugas nei ịprastos tradicinès finansinès institucijos. Tai apima plačias sritis nuo duomenų apsaugos iki finansinių paslaugų teikimo (Gai et al., 2018). Šiame tyrime fintech yra finansinès technologijos naudojamos komerciniuose bankuose siekiant palengvinti paslaugų teikimą, jų kokybę bei pagerinti vartotojų patirtị.

Komercinis bankas yra finansinių paslaugų teikejjas, siekiantis pelningai išnaudoti turimus išteklius ir suteikti grąž̨a investuotojams. Tai yra patys dinamiškiausi finansiniai tarpininkai, kurie atlieka svarbiausias finansines funkcijas ịvairiose pasaulio ekonomikose: rizikos perkèlimas, sudètingų finansinių priemonių naudojimas rinkose, rinkos skaidrumo užtikrinimas, mokèjimo operacijos, pasiūlos ir paklausos finansų rinkose reguliavimas, taip pat rizikos valdymo funkcija (Olalere et al., 2017).

\subsection{Finansinès technologijos komerciniuose bankuose}

Žvelgiant $\mathfrak{i}$ finansiniu paslaugu sektoriaus istoriją finansinès technologijos pradëjo vystytis nuo informaciniu technologiju pažangos. Ivairūs autoriai, pavyzdžiui Joshi ir Parihar (2017), Alt et al. (2018), Bhagyashree (2018) nagrinėja finansinių paslaugų ir technologijų tobulèjimo istoriją. Pirmujjų bankų ir prekybos įmonių naudojamos technologijos buvo paremtos fizinėmis laikmenomis, kuriose buvo saugoma informacija ir vertè (pvz. Popierius ar monetos). Tai ribojo rinkos tiekejjus paslaugas teikti tik regiono ribose, kadangi informacijos perdavimas buvo sudètingas, tačiau atsiradus naujovèms informacinèse ir ryšiu technologijose (IT) informacijos perdavimas tapo lengvesnis jau nuo telegrafo atsiradimo. Ekonominiai padariniai buvo esminiai, prasidejusi skaitmeninès informacijos ir ryšių technologijų tobulèjimui, tai lèmè skaitmeninių finansinių technologijų eros pradžią, kartais dar vadinamą ,efinansais". Tuomet finansinès paslaugos tapo priklausomos nuo elektroninių sandorių tarp finansų institucijų, finansų rinkos dalyvių ir klientų visame pasaulyje, o labiausiai tai buvo pritaikyta bankuose. Remiantis Joshi ir Parihar (2017) elektroninės bankininkystės raida prasidejo Didžiojoje Britanijoje ir JAV 1920-aisiais ir ypač populiari septintajame dešimtmetyje. XXI amžiuje internetas ir mobiliosios technologijos vis labiau populiareja ir daro įtaką kiekvieno proceso, iskaitant ir finansines paslaugas, veikimui. Bankai skiria dideles investicijas siekdami patenkinti klientu poreikius bei siekdami išlaikyti savo konkurencini pranašumą.

Šiuo metu technologijos pasaulyje nuolatos tobuleja, o komerciniai bankai stengiasi išnaudoti visas jų teikiamas galimybes. Finansinès technologijos išvardintos 1 lentelëje remiantis literatūros analize yra ịvardijamos kaip pagrindinès finansinès technologijos pritaikytos bankuose.

1 lentelè. Komercinių bankų naudojamos finansinès technologijos ir jų apibūdinimai (sudaryta autorių remiantis Joshi ir Parihar, 2017; Bhagyashree, 2018; Thakor, 2020; Gupta et al., 2018; Gupta ir Yadav, 2017; Rega, 2017)

\begin{tabular}{|c|c|}
\hline Finansinès technologijos & Aprašymas \\
\hline $\begin{array}{l}\text { Bankomatas (angl. ATM-automated teller } \\
\text { machine) }\end{array}$ & $\begin{array}{l}\text { Suteikia klientams galimybę išsigryninti ar įnešti pinigus ị banko } \\
\text { sąskaitą bet kuriuo paros metu. Tam nereikalingas banko darbuotojas, } \\
\text { užtenka turèti banko kortelę }\end{array}$ \\
\hline Internetinė bankininkystė & $\begin{array}{l}\text { Suteikia klientams galimybę daugelị bankinių paslaugų atlikti patiems } \\
\text { naudojantis interneto banku: pavedimai, paraiškų pildymas, sąskaitų } \\
\text { likučio peržiūra, limitu keitimai ir kt. paslaugos }\end{array}$ \\
\hline $\begin{array}{l}\text { Mobilioji bankininkystė (mobilioji } \\
\text { programėlė) }\end{array}$ & $\begin{array}{l}\text { Interneto banko naudojimas mobiliajame telefone suteikia klientams } \\
\text { galimybę greitai atlikti pavedimus ir kitas paslaugas mobiliojoje } \\
\text { programėleje }\end{array}$ \\
\hline $\begin{array}{l}\text { Periodinių mokèjimų Sistema (ịmokos) (angl. } \\
\text { ECS-Electronic clearance services) }\end{array}$ & $\begin{array}{l}\text { Tai yra ruošiniai periodiniams mokėjimams, paskirstant dideles sumas } \\
\text { ar surenkant dideles sumas iš atskiru įmokų. (pvz., mènesiniai } \\
\text { mokesčių mokejjimai, atlyginimų išmokèjimai ir pan.) }\end{array}$ \\
\hline $\begin{array}{l}\text { Nuotolinės konsultacijos telefonu (angl. } \\
\text { Telebanking) }\end{array}$ & $\begin{array}{l}\text { Galimybė klientams gauti reikiamas finansines konsultacijas } \\
\text { neatvykus i banką, o paskambinus telefonu. Klientų identifikavimas ir } \\
\text { banko paslaugų ar konsultacijų suteikimas visa parą telefonu }\end{array}$ \\
\hline
\end{tabular}


1 lentelès pabaiga

\begin{tabular}{|l|l|}
\hline \multicolumn{1}{|c|}{ Finansinės technologijos } & \multicolumn{1}{c|}{ Aprašymas } \\
\hline $\begin{array}{l}\text { Bankinių kortelių skaitytuvai (angl. EFTPOST- } \\
\text { Electronic fund tranfer at the Point of sale } \\
\text { terminal) }\end{array}$ & $\begin{array}{l}\text { Terminalas prijungtas prie klientų informacijos banke, kuris nuskaito } \\
\text { užkoduotas bankines korteles, identifikuoja klientą ir atlieka kliento } \\
\text { sąskaitos debetavimą sumokant už pirkinius, o mažmenininko } \\
\text { sąskaitos kreditavimą }\end{array}$ \\
\hline SWIFT & Tarptautinių tarpbankinių atsiskaitymų sistema \\
\hline Debetinė ir kreditinė banko kortelė & $\begin{array}{l}\text { Plastikinė kortelè, kuri gali būti naudojama vietoje grynujų pinigu } \\
\text { atsiskaitant už pirkinius. Naudojant debetinę kortelę lëšos yra } \\
\text { tiesiogiai nuskaitomos nuo kliento banko sąskaitos, naudojant } \\
\text { kreditinę kortelę lěšos gali būti paskolinamos iš banko pagal sutartas } \\
\text { sąlygas }\end{array}$ \\
\hline $\begin{array}{l}\text { Centralizuotas duomenu valdymas (angl. } \\
\text { Core })\end{array}$ & $\begin{array}{l}\text { Visi banko duomenys valdomi centralizuotai ir yra prieinami tolygiai } \\
\text { visiems banko skyriams, tai automatizuoja bankų veikimą }\end{array}$ \\
\hline
\end{tabular}

Daug komercinių bankų nuolat pildo savo naudojamų finansinių technologijų sąrašą ir siekia vieni su kitais konkuruoti teikiamomis paslaugomis. Bhagyashree (2018) išskiria šias inovacijas, kurios pritaikomos bankuose: biometrinis autentifikavimas (pirštų antspaudų, DNR, tinklainès ir veido atpažinimas), automobilio programų susiejimas su banko mobiliaja programèle (suteikia galimybę atlikti mokèjimus, patikrinti sąskaitų likučius balsu valdant programą), kriptovaliutos, išmanieji laikrodžiai, robotika, dirbtinis intelektas.

Elektroninè bankininkysté, bankomatai, debetinès ir kreditinès kortelès, mobiliosios banko programèlès, elektroniniai mokèjimai ir kitos finansinès technologijos palengvina finansinių paslaugų prieinamumą banko klientams, kurie nenori vykti ị banko skyrių ir laukti eilèse. Šios technologijos pakeitė bankų veiklą, kurie pagreitina savo paslaugų procesus, taupo išlaidas ir laiką. Finansinių technologijų vystymas banko veikloje ne visada yra vertinamas teigiamai ir teikia tik naudą. Ivvairūs autoriai, analizuodami finansinių technologijų pritaikymą komercinių bankų veikloje, išskiria jų teikiamą naudą ir trūkumus (2 lentelè). Finansinès technologijos bankams suteikia galimybę praplèsti klientų segmentą, produktų pasiūlą, galimybes plètoti veiklą naujose rinkose, o tai sukuria naujus pajamų srautus banko veikloje ir didina efektyvumą. Finansinès technologijos teikia galimybes ir naudą ne tik komerciniams bankams, tačiau ir klientams. Tai pagreitina klientų aptarnavimą, mažiau rankų darbo ir popierinių dokumentų pildymo, paslaugos ir problemos gali būti nedelsiant sprendžiamos nuotoliniu būdu, mažèja klientų eilès bankų skyriuose, paslaugos yra suteikiamos efektyviau (Drasch et al., 2018), o tai pagerina vartotojų patirtí. Iš kitos pusès, vertinant finansines technologijas, reikia pastebėti, kad iškyla duomenų apsaugos, sukčiavimo ir informacijos praradimo tikimybè. Taip pat, reikia ịvertinti galimas technines kliūtis ar tinklo problemas vykdant veiklą. Šios grèsmès turi būti įvertintos kiekvieno komercinio banko, kuris nori užtikrinti patikimumą bei stabilumą savo veikloje teikiant kokybiškas paslaugas.

2 lentelè. Finansinių technologijų teikiama nauda ir trūkumai (sudaryta autorių remiantis Joshi ir Parihar, 2017; Gupta ir Yadav, 2017; Bhagyashree, 2018; Ky et al., 2019)

\begin{tabular}{|l|l|}
\hline \multicolumn{1}{|c|}{ Finansinių technologijų nauda } & \multicolumn{1}{c|}{ Finansinių technologijų trūkumai } \\
\hline Naujų klientų segmentų, produktų ir paslaugų plètra & $\begin{array}{l}\text { Informacijos saugumo trūkumas, grèsmė prarasti } \\
\text { informaciją }\end{array}$ \\
\hline Generuoja naujus pajamų srautus ir padidina efektyvumą & Techninės kliūtys vykdant operacijas, tinklo problemos \\
\hline $\begin{array}{l}\text { Sumažina popierinių dokumentų pildymą ir pagreitina } \\
\text { teikiamas paslaugas }\end{array}$ & Sukčiavimo galimybės \\
\hline Geresnis ir greitesnis klientų poreikių supratimas & Papildomi ištekliai ir išlaidos kuriant IT sistemas \\
\hline Patobulintas sprendimų prièmimas & Reguliarus IT darbuotojų IT žinių tobulinimas \\
\hline Greitesnis lèšų judèjimas & Didelių duomenų sujungimo problemos \\
\hline Darbuotojų darbo ir produktyvumo gerinimas & Operacinės rizikos atsiradimas \\
\hline $\begin{array}{l}\text { Sutaupo darbuotojų ir klientų laiką, didina klientų } \\
\text { pasitenkinimą }\end{array}$ & \\
\hline Sumažina išlaidas ir palengvina operacijas & \\
\hline $\begin{array}{l}\text { Duomenų prieinamumas analizei siekiant ieškoti veiklos } \\
\text { tobulinimo }\end{array}$ & \\
\hline Daugiau bankinių operacijų ir naujausia informacija & \\
\hline Mažiau reikalingų darbuotojų atlikti operacijas & \\
\hline
\end{tabular}


Inovacijų ir technologijų vystymasis skatina pasaulines rinkas digitalizuoti savo veiklą ir investituoti i inovacijas. Komerciniai bankai siekdami išlikti finansų rinkose nuolatos investuoja ir diegia ịvairias finansines technologijas savo veikloje: bankomatai, mokejjimo kortelès, mokèjimo kortelių skaitytuvai, periodiniai mokèjimai, elektroninè bankininkystė, mobiliosios programèlès, duomenų valdyo sistemos. Šių finansinių technologijų diegimas ne tik palengvina banko procesus ir paslaugų teikimą klientams, tačiau reikalauja komercinių bankų investicijų ir pasiruošimo jas efektyviai pritaikyti veikloje.

\subsection{Komercinių bankų pelningumo vertinimas}

Komercinių bankų pelningumas yra plačiai nagrinėta tema. Pelningumą galima apibrèžti kaip bankų gebejjimą gauti pelną iš savo verslo veiklos. Pelningumas yra pagrindinis pajamų šaltinis, kuris matuoja įmonès rezultatus siekiant išreikšti bankų konkurencinę padėtị bankų rinkoje ir kokybès valdymą. Dažnai tai gali būti nagrinèjama remiantis grynojo pelno pokyčiais, daug autorių teigia, kad komercinio banko pelningumą parodo turto grąžos (toliau ROA) ir nuosavo kapitalo grąžos (toliau ROE) rodikliai. Remiantis Petria et al. (2015) tyrimu, banko pelningumą geriau vertinti naudojant vidutinị turto grąžos (toliau ROAA) ir vidutini nuosavo kapitalo grąžos rodikli (toliau ROAE), tuomet pelningumas įvertinamas tiksliau nei naudojant metu pabaigos reikšmes. Kiti autoriai prideda, kad banko pelningumo vertinimui galima naudoti pagal riziką įvertinto turto pelningumo rodiklị (toliau RORA), bei grynujų palūkanų pajamų maržos rodiklị (toliau NIM) (3 lentelè). ROA rodiklis dažniausiai naudojamas norint ịvertinti vidinius banko sugebėjimus uždirbti pelno. Komerciniuose bankuose alternatyvus ir dar svarbesnis pelningumo rodiklis yra ROE. Šis rodiklis yra praktiškesnis, nes investuotojai gali įvertinti savo investicijų grąžą. Bet kuriuo atveju, Cheng ir Mevis (2019) teigia, kad tarp ROE ir ROA yra linijinis ryšys, įrodytas DuPont analize.

3 lentelè. Komercinio banko pelningumo vertinimo rodikliai (sudaryta autorių)

\begin{tabular}{|c|c|c|}
\hline $\begin{array}{c}\text { Pelningumo } \\
\text { rodiklis }\end{array}$ & Aprašymas & Autoriai \\
\hline ROA, ROAA & $\begin{array}{l}\text { Šis rodiklis rodo grynojo pelno ir viso turto santykį. } \\
\text { Veiklos efektyvumas matuojamas remiantis įmonių } \\
\text { sugeneruotu pelnu iš viso turto, tai išsamiai parodo } \\
\text { imonės veiklos rezultatus, vertinant tiek pelno } \\
\text { (nuostolių) ataskaitos rezultatus, tiek turtą, kuris } \\
\text { įmonei reikalingas savo verslui vykdyti }\end{array}$ & $\begin{array}{l}\text { (Abate ir Mesfin, 2019), (Suppia ir } \\
\text { Arshad, 2019), (Ramadhanti et al., } \\
\text { 2019), (Rehman et al., 2018), } \\
\text { (Djalilov ir Piesse, 2016), (Skvarciany } \\
\text { ir Simanavičiūte, 2018), (Nuhiu et al., } \\
\text { 2017), (Marozva, 2015) }\end{array}$ \\
\hline ROE, ROAE & $\begin{array}{l}\text { Šis rodiklis rodo grynojo pelno ir viso nuosavo } \\
\text { kapitalo santykį. Paprastai šis rodiklis yra } \\
\text { aktualiausias inevstuotojams, norint įvertinti } \\
\text { investicijų naudingumą ir pelningumą. Rodiklis } \\
\text { laikomas akcininkų grąžos mato vienetu }\end{array}$ & $\begin{array}{l}\text { (Saiful ir Ayu, 2019), (Javed ir } \\
\text { Basheer, 2017), (Skvarciany ir } \\
\text { Simanavičiūte, 2018), (Nuhiu et al., } \\
\text { 2017), (Marozva, 2015) }\end{array}$ \\
\hline RORA & $\begin{array}{l}\text { Šis rodiklis yra artimas turto grąžos rodikliui, tačiau } \\
\text { vertinant yra atsižvelgiama į banko turto investiciju } \\
\text { rizikingumą. Tai parodo grynojo pelno ir turto } \\
\text { įvertinto pagal riziką santykį. Didesnės rodiklis rodo } \\
\text { geresnius banko valdymo rezultatus }\end{array}$ & $\begin{array}{l}\text { (Skvarciany ir Simanavičiūtè, } \\
\text { 2018), (Salhuteru ir Wattimena, } \\
\text { 2015), }\end{array}$ \\
\hline NIM & $\begin{array}{l}\text { Šis rodiklis parodo banko parindinès veiklos } \\
\text { pelnigumą (kreditavimas, lěšos už kurias mokamos } \\
\text { palūkanos). Tai yra grynujų palūkanų pajamų ir turto } \\
\text { santykis. Žemas rodiklis ǐspėja, kad bankas neuždirba } \\
\text { pakankamai pajamų už išduotas paskolas arba moka } \\
\text { per dideles palūkanas už indèlius }\end{array}$ & $\begin{array}{l}\text { (Nuhiu et al., 2017), (Abbas et al., } \\
\text { 2019), (Marozva, 2015) }\end{array}$ \\
\hline $\begin{array}{l}\text { Palūkanas } \\
\text { uždirbančio turto } \\
\text { pajamingumas } \\
\text { (toliau YEA) }\end{array}$ & $\begin{array}{l}\text { Rodiklis apskaičiuojamas padalijus palūkanas už } \\
\text { uždirbtą turtą iš vidutinės šio turto vertės per } \\
\text { laikotarpi. Šiuo rodikliu atsižvelgiama ì grynosioms } \\
\text { pajamoms įtaką darančius komponentus (turas } \\
\text { uždirbantis palūkanas) }\end{array}$ & $\begin{array}{l}\text { (Phan et al., 2019), (Ghebregiorgis ir } \\
\text { Atewebrhan, 2016), }\end{array}$ \\
\hline
\end{tabular}

Ivertinus autorių patekiamus rodiklius vertinant komercinių bankų veiklos rezultatus ir pelningumą, plačiai naudojami ROA ir (Phan et al., 2019) ROE rodikliai. Bankų reguliuotojai ir analitikai panaudojo ROA ir ROE, kad ịvertintų pramonès rezultatus ir prognozuotų rinkos struktūros tendencijas - kaip statistinių modelių indèlį numatant bankų žlugimus ir susijungimus - ir įvairiais kitais tikslais, kai norima ịvertinti pelningumą.

Finansinès technologijos komerciniuose bankuose nuolatos tobulèja ir kuriasi jau keletą dešimtmečių. Šios inovacijos komercinių bankų veikoje turi ne tik privalumų, tokių kaip, greitesni procesai, geresnè klientų patirtis, sumažeję išlaidos teikiant paslaugas ir pan. Taip pat finansinių technologijų atsiradimas komercinių bankų veikloje 
sukelia sunkumų bankams valdant technologijų priežiūrą ir duomenų saugumą, išauga investicinès išlaidos, darbuotojų kvalifikacijos kèlimas technologijų srityje ir pan. Dėl šių priežasčių yra labai svarbu ịvertinti, kokią finansinę naudą finansinès tachnologijos teikia komerciniams bankams ir kaip tai daro įtaką komercinio banko pelningumui.

\subsection{Finansinių technologijų ịtaka komercinių bankų pelningumui}

Moksliniuose tyrimuose finansinių technologijų naudojimas komerciniuose bankuose buvo tiriamas įvairiais aspektais. Atliekant tyrimus mokslininkai siekia nustatyta ar finansinių technologijų diegimas ir naudojimas komercinių bankų veikloje daro itaką pelningumo ar kitiems veiklos rodikliams. Remiantis teoriniais aspektais finansinès technologijos reikalauja daug investicijų, tačiau sumažina kitas banko patiriamas išlaidas. Finansinès technologijos pritaikytos komerciniuose bankuose palengvina ir pagreitina paslaugų suteikimą klientams, sumažina darbuotojų darbo krūvị, sumažina žmogiškojo faktoriaus klaidų atsiradimo riziką ir sumažina paslsugų suteikimo kaštus, kadangi daugiau operacijų gali atlikti patys klientai be darbuotojų pagalbos. Tačiau žvelgiant ị banko finansinius duomenis kyla klausimas kokią itaką finansiniams banko pelningumo rodikliams daro naudojamos finansinès technologijos. Ivairių mokslininkų nuomonès išsiskiria ir nesutampa.

Ky et al. (2019) nustatè, kad yra teigiamas ir reikšmingas ryšys tarp mobiliųų pinigų naudojimo ir banko veiklos rezultatų, atsižvelgiant i pelningumą, efektyvumą ir stabilumą. Tačiau Gupta et al. (2018) tirdamas Indijos bankų rezultatus ir finansinių technologijų itaką, nustatè, kad yra statistiškai reikšmingas neigiamas ryšys tarp ROA rodiklio ir finansinių technologijų. Šis autorius teigia, kad Indijos bankininkystės sektoriuje yra pelningumo paradoksas remiantis gautais rezultatais. Italijos rinką vertino Ciciretti et al. (2009), kurie nustatė reikšmingą teigiamą ryši tarp internetinès bankininkystès produktų pasiūlos ir Italijos bankų veiklos rezultatų (matuojant ROE, ROA, mokesčių pajamas ir komisinius) bei reikšmingą neigiamą ryši tarp internetinės bankininkystès sprendimų ir bankų rizikos. Bangladeše Islam et al. (2019) tyrè interneto banko banko daromą ịtaką pelningumui, tačiau nors ir rezultatai ịrodė, kad interneto bankas daro teigiamą įtaką, bet rezultatai nėra reikšmingi komercinių bankų pelningumo rodikliams ROA ir ROE. Vertinant Europos Sajungos šalis ir kitas šalis, Akhisar et al. (2015) pastebejo, kad finansinių technologijų teigiama ịtaka bankų rezultatams yra labiau juntama Europos sajungos šalyse, kuriose technologijų naudojimas labiau išsivystęs. Tai lemia klientų požiūris ị technologijų naudojimą, šalies išsivystymo lygis. Kiti autoriai daugiau dèmesio skyrė atskiriems kintamiesiems vertindami finansines technologijas komerciniuose bankuose. Fuster et al. (2019) pateikia ịrodymų, kad finansinès technologijos pagerino hipotekos paskolų produktyvumą, o Scott et al. (2017) nustatè, kad SWIFT mokèjimų tinklo sistemos prièmimas daro dideli poveikị ilgalaikiam banko pelningumui ir mokèjimų tinklo veikimui. Apibendrinant jau atliktų tyrimų rezultatus, minèti autoriai nustate, kad finansinių technologijų naudojimas užtikrina privatumą, paslaugų kokybę, patogiai perduoda informaciją banke, padidina paslaugų spektrą ir taip pat sumažina paslaugų kainas. Vertinant įtaką skirtoge šalyse komercinių bankų pelningumui rezultatai skirtingi, tačiau taip pat reikia atsižvelgti į šalių išsivystymo lygi bei ekonominę situaciją. Remiantis autorių atliktais tyrimais ir nuomonès keliamos šios hipotezès:

- H1: Mokèjimo kortelių naudojimas daro teigiamą įtaką komercinių bankų pelningumo rodikliams.

- H2: Bankomatų naudojimas daro teigiamą ịtaką komercinių bankų pelningumo rodikliams.

- H3: Kortelių skaitytuvų naudojimas daro teigiamą ịtaką komercinių bankų pelningumo rodikliams.

- H4: Interneto banko naudojimas daro teigiamą įtaką komercinių bankų pelningumo rodikliams.

\section{Finansinių technologijų ịtakos komercinio banko pelninigumui skaičiavimo metodologija}

Išanalizavus mokslinę literatūrą komercinio banko pelningumo vertinimui naudojama finansiniai rodikliai: ROA, ROE, NIM. Šiame tyrime bus naudojamas ROA (žr. (1)), kuris parodo, banko turimo turto panaudojimo efektyvumas. Šis rodiklis skaičiuojamas vertinant grynųų pajamų ir turto santykị. Turto pelningumui nustatyti rekomenduojama apskaičiuoti vidutinị turtą, ypač jei turtas per metus ženkliai pasikeičia. Kuo didesnis santykis, tuo geriau komerciniame banke naudojamas turtas. Neigiamas rodiklis įspejja, kad turtas neduoda pelno ir yra naudojamas neefektyviai, galbūt jo nereikia. Dèl kredito įstaigos veiklos specifikos, kai pagrindinès pajamos uždirbamos ir gaunamas pelnas iš palūkanų, komisinių, šis rodiklis yra daug mažesnis nei kitose įmonèse ir paprastai siekia tik vieną ar du procentus (Tran et al., 2016).

$$
\mathrm{ROA}=\frac{\mathrm{GP}}{\mathrm{T}}
$$

čia: ROA - turto grąžos rodiklis; GP - grynasis pelnas; T - visas turtas.

Taip pat, komercinio banko pelningumo vertinimui bus naudojamas ir rodiklis ROE (žr. (2)) (Abraham et al., 2017), kuris parodo kaip efektyviai yra naudojamas kapitalas bei kokią grąžą jis uždirba. Žemas rodiklis įspejja apie neefektyvų kapitalo naudojimą bei apie galimai perteklinį nuosavą kapitalą. 


$$
\mathrm{ROE}=\frac{\mathrm{GP}}{K},
$$

čia: ROE - nuosavo kapitalo grąžos rodiklis; GP - grynasis pelnas; $K$ - nuosavas kapitalas.

Linijinė regresija įvertina tiesinės lygties koeficientus, apimančius vieną ar daugiau nepriklausomų kintamujų, kurie geriausiai numato priklausomo kintamojo vertę. Atlikus linijinę regresinę analizę gaunama kintamujų reikšmingumas ir ịtaka priklausomam kintamajam. Tai leidžia ịvertinti ar pasirinkti kintamieji iš tiesų daro ịtaką pasirinktam kintamajam. Vertinant finansinių technologijų ịtaką, gali būti naudojami ịvairūs regresijos modeliai, kurie parodo ryši tarp kintamujų (Li et al., 2016). Tai parodo santykị tarp kintamujų, tačiau skaičiuojant daugiau nei vienos finansų ịstaigos rezultatus per tam tikrą laikotarpi, turètų būti naudojama panelinių duomenų regresija. Paneliniai duomenys yra sudaryti iš laiko eilučių duomenų ir skerspjūvio duomenų. Tai yra kintamujų stebẻjimas laike ir stebimų objektų kintamųjų reikšmių fiksavimas konkrečiu laiku. Panelinių duomenų modeli gali sudaryti vienas ar keli nepriklausomi kintamieji (̌̌r. (3)).

$$
Y_{i, t}=\alpha_{i}+\beta X_{i, t}+u_{i, t}
$$

čia: $Y_{i, t}-$ priklausomas kintamasis; $X_{i, t}$ - nepriklausomi kintamieji; $u_{i, \mathrm{t}}-$ paklaida; $i=1, \ldots, \mathrm{n}, t=1, \ldots, \mathrm{t} ; \beta-$ koeficientas; $\alpha$ - laisvasis narys.

Paneliniai duomenys gali būti analizuojami 3 modeliais:

- Pastovios konstantos modeliai (angl. Pooled model). Šiame modelyje daroma prielaida, kad stebimi objektai yra homogeniški, $\alpha$ yra lygi visiems objektams. Svarbu atkreipti dèmesị, kad šiame modelyje yra tiketina paklaidų autokoreliacija.

- Fiksuoto poveikio modeliai (angl. Fixed effects model). Šiame modelyje daroma prielaida, kad stebimi objektai nèra homogeniški, o $\alpha$ visiems objektams skiriasi. Šiame modelyje yra tikètinas multikolinearumas tarp fiksuotų efektų ir lètai laike kintančių nepriklausomų kintamųjų.

- Atsitiktinio poveikio modeliai (angl. Random effects model). Šiame modelyje yra daroma prielaida, kad stebimi objektai yra skirtingi ir atsitiktinio pobūdžio. Modelio konstanta yra vienoda visiems objektas, o paklaidos skiriasi.

Panelinių duomenų regresija gali būti naudojama ịvairių tipų duomenims, tačiau yra keletas apribojimų ir reikalavimų (Pindado ir Requejo, 2015):

- Regresijos parametrų reikšmingumo tikrinimas. Regresijos statistinis reikšmingumas apskaičiuojamas naudojant Stjudento testą. Rezultatas laikomas reikšmingu, jei $\mathrm{p}<0,05$. Modelyje turètų būti naudojami tik reikšmingi kintamieji.

- Sukurto modelio reikšmingumo patikrinimas. Reikšmingumo tikrinimui naudojama Fišerio kriterijus. Statistiškai reikšmingas Fišerio kriterijus yra $<0,01$, o tai rodo, kad bent vienas iš modelio parametrų regresijos lygtyje turi didelę ịtaką nepriklausomam kintamajam.

- Modelio tikslumo ivvertinimas. Regresijos modelio tikslumui ịvertinti naudojamas r-kvadrato koeficientas, kuris rodo, kurią priklausomo kintamojo variacijos dali galima paaiškinti nepriklausomais kintamaisiais. Šis koeficientas paprastai išreiškiamas procentais. R-kvadrato koeficiento reikšmè gali būti nuo -1 iki 1 . Kuo didesnè jo vertè, tuo tikslesnis modelis. Jei R kvadratas lygus 1 , modelis be jokių abejonių gali būti paaiškintas kintamaisiais.

Laikantis šių apribojimų ir šio modelio specifikacijų, finansinių technologijų poveikis komercinių bankų pelninigumui gali būti ịvertintas naudojant duomenų analizès programas. Panelinių duomenų regresijos modelis gali nustatyti kintamujuc įtaką.

\section{Finansinių technologijų ịtakos Lietuvos komercinių bankų pelningumo rezultatams skaičiavimas}

Atliekant tyrimą buvo naudoti trijų didžiausių Lietuvoje veikiančių komercinių bankų rezultatai nuo $2014 \mathrm{~m}$. iki 2018 m. Priklausomas kintamasis (Y) - ROA ir ROE. Nepriklausomi kintamieji: mokejjimo korteliu skaičius (toliau CARDS), bankomatų skaičius (toliau ATM), mokejjimo kortelių skaitytuvų skaičius (toliau EFTPOST), internetinès bankininkystès registruotų vartotojų skaičius (toliau E-Bank).

Kadangi tyrimui reikalingų viešai prieinamų duomenų kiekis nėra didelis, buvo analizuojama visų trijų komercinių bankų duomenys kartu naudojant panelinių duomenų regresijos fiksuoto poveikio modeli ir pastovios konstantos modeli. Siekiant gauti tikslesnius atsakymus, skaičiavimai buvo atlikti abiem modeliais siekiant palyginti gautus rezultatus. Regresinè analizė buvo atlikta naudojant Microsoft Excel statistinès analizès papildinị XLSTAT.

Panelinių duomenų regresija dviem modeliais buvo atlikta atskirai naudojant priklausomus kintamuosius ROA ir ROE. 4 lentelèje pateikiami gauti rezultatai skaičiuojant finansinių technologijų įtaką komercinių bankų ROA rodikliui fiksuoto poveikio modeliu (angl. fixed effect model) ir pastovios konstantos modelio (angl. pooled efffect model) rezultatai. Fiksuoto poveikio modelio rezultatai rodo, kad rezultatai nėra reikšmingi, kadangi Fišerio kriterijus yra daugiau nei 0,01 . Vertinant modelio tikslumą, taip rezultatai yra žemi, kadangi modelis yra paaiškinamas tik 
28 \%. Peržiūrèjus pagrindines modelio charakteristikas modelis reikšmingų rezultatų nepateikè. Tuo ịsitikinti galima ir peržiūrèjus Stjudento testo rezultatus kiekienam nepriklausomam kintamajam $\operatorname{Pr}(>|t|)$ yra didesni už 0,05 . Analizuojant pastovios konstantos modelio rezultatus, duomenys paaiškiną beveik 57 \% modelio, o tai yra $29 \%$ daugiau nei fiksuoto modelio rezultatas. Fišerio kriterijus yra mažesnis už 0,01, ir yra statistiškai reikšmingas. Kintamieji turi reikšmingos ịtakos nepriklausomam kintamajam, tačiau vertinant Stjudento testo rezultatus, reikšmingų kintamųjų modelyje nèra.

4 lentelè. Finansinių technologijų ịtaka komercinio banko ROA rodikliui fiksuoto poveikio modelio rezultatai ir pastovios konstantos modelio rezultatai (sudaryta autorių)

\begin{tabular}{|c|c|c|c|c|c|c|c|c|c|}
\hline \multicolumn{5}{|c|}{ Fiksuoto poveikio modelis } & \multicolumn{5}{|c|}{ Pastoviosios konstantos modelis } \\
\hline rsq & 0,283 & & & & rsq & 0,569 & & & \\
\hline adjrsq & $-0,315$ & & & & adjrsq & 0,526 & & & \\
\hline p.value.F & 0,081 & & & & p.value.F & $<0.0001$ & & & \\
\hline \multicolumn{5}{|c|}{ Koeficientai: } & \multicolumn{5}{|c|}{ Koeficientai: } \\
\hline & $\begin{array}{c}\text { Apskaičiuotas } \\
\text { koeficientas }\end{array}$ & $\begin{array}{l}\text { Std. } \\
\text { Error }\end{array}$ & t-value & $\operatorname{Pr}(>|t|)$ & & $\begin{array}{c}\text { Apskaičiuotas } \\
\text { koeficientas }\end{array}$ & $\begin{array}{c}\text { Std. } \\
\text { Error }\end{array}$ & t-value & $\operatorname{Pr}(>|t|)$ \\
\hline & & & & & $\alpha$ & $-0,086$ & 0,519 & $-0,165$ & 0,870 \\
\hline CARDS & 0,000 & 0,000 & $-0,475$ & 0,639 & CARDS & 0,000 & 0,000 & 1,504 & 0,140 \\
\hline ATM & 0,011 & 0,010 & 1,081 & 0,291 & ATM & 0,004 & 0,005 & 0,765 & 0,449 \\
\hline EFTPOST & 0,000 & 0,000 & 1,707 & 0,101 & EFTPOST & 0,000 & 0,000 & $-0,628$ & 0,534 \\
\hline E-BANK & 0,000 & 0,000 & $-0,913$ & 0,370 & E-BANK & 0,000 & 0,000 & $-0,999$ & 0,324 \\
\hline
\end{tabular}

Apibendrinant abiejų modelių rezultatus, gauti modeliai nėra statistiškai reikšmingi ir nedaro reikšmingos įtakos komercinių bankų ROA rodikliui. Nors ir rezultatai nėra reikšmingi, tačiau galima atkreipti dėmesi gautus koeficientus, kadangi tik bankomatų naudojimas yra darantis labai silpną, tačiau nereikšmingą teigiamą ịtaką komercinių bankų ROA rodikliui.

5 lenteleje yra pateikiami fiksuoto poveikio modelio ir pastovios konstantos modelio razultatai vertinant priklausomą kintamajj ROE. Rezultatai yra panašūs ị ROA rodiklio modelių rezultatus. Fiksuoto poveikio modelio kintamieji paaiškina beveik $23 \%$ modelio, o pastovaus kintamojo modelio - 51 \%. Lyginant Fišerio kriterijaus rezultatus, pastovaus kintamojo modelio rezultatai yra reikšmingi, rezultatas yra mažesnis už 0,0001 . Tačiau vertinant kiekvieno nepriklausomo kintamojo gautų rezultatų reikšmingumą, nėra nei vieno statistiškai reikšmingo nepriklausomo kintamojo. Stjudento testo rezultatai $\operatorname{Pr}(>|t|)$ visų kintamujų yra didesni už 0,05. Nors vertinant finansinių technologijų įtaką komercinio banko ROE rodikliui gauti koeficientai parodè silpną bankomatų ir mokejjimo kortelių skaitytuvų ịtaką komercinių bankų pelninigumui, tačiau abiem modeliais gauti rezultatai nėra statistiškai reikšmingi ir šios finansinès technologijos nedaro reikšmingos įtakos komercinių bankų ROE rodikliui.

5 lentelè. Finansinių technologijų įtaka komercinio banko ROE rodikliui fiksuoto poveikio modelio rezultatai ir pastovios konstantos modelio rezultatai (sudaryta autorių)

\begin{tabular}{|c|c|c|c|c|c|c|c|c|c|}
\hline \multicolumn{5}{|c|}{ Fiksuoto poveikio modelis } & \multicolumn{5}{|c|}{ Pastoviosios konstantos modelis } \\
\hline rsq & 0,229 & & & & rsq & 0,505 & & & \\
\hline adjrsq & $-0,414$ & & & & adjrsq & 0,456 & & & \\
\hline p.value.F & 0,166 & & & & p.value.F & $<0.0001$ & & & \\
\hline \multicolumn{5}{|c|}{ Koeficientai: } & \multicolumn{5}{|c|}{ Koeficientai: } \\
\hline & $\begin{array}{c}\text { Apskaičiuotas } \\
\text { koeficientas }\end{array}$ & $\begin{array}{c}\text { Std. } \\
\text { Error }\end{array}$ & t-value & $\operatorname{Pr}(>|t|)$ & & $\begin{array}{c}\text { Apskaičiuotas } \\
\text { koeficientas }\end{array}$ & $\begin{array}{c}\text { Std. } \\
\text { Error }\end{array}$ & t-value & $\operatorname{Pr}(>|t|)$ \\
\hline & & & & & $\alpha$ & 0,768 & 3,673 & 0,209 & 0,835 \\
\hline CARDS & 0,000 & 0,000 & $-0,376$ & 0,710 & CARDS & 0,000 & 0,000 & 1,304 & 0,200 \\
\hline ATM & 0,023 & 0,071 & 0,329 & 0,745 & ATM & 0,007 & 0,035 & 0,202 & 0,841 \\
\hline EFTPOST & 0,002 & 0,001 & 1,779 & 0,088 & EFTPOST & 0,000 & 0,000 & 0,604 & 0,549 \\
\hline E-BANK & 0,000 & 0,000 & $-0,944$ & 0,354 & E-BANK & 0,000 & 0,000 & $-0,528$ & 0,600 \\
\hline
\end{tabular}

Tyrimo rezultatai atskleidè, kad mokèjimo kortelių naudojimas, bankomatų naudojimas, mokejjimo kortelių skaitytuvų naudojimas ir elektroninės bankininkystės naudojimas nèra reikšmingai darantys įtaką veiksniai komercinių bankų pelningumo rodikliams vertinant ROA ir ROE rodiklius. Taip pat, nors ir nereikšmingai, tačiau iš visų vertintų finansinių technologijų bankomatų naudojimas visuose modeliuose daro nereikšmingą labai silpną teigiamą įtaką pelningumo rodikliams. Atlikus visus skaičiavimus, iškeltos hipotezès yra atmetamos, kadangi nei viena finansinè technologija nedaro reikšmingos įtakos komercinių bankų pelningumo rodikliams. Apibendrinant 
rezultatuas, svarbu atkreipti dèmesị, kad tyrimai atlikti naudojant pastovios konstantos modeli statistiškai pateikè reikšmingesnius ir patikimesnius rezultatus nei fiksuoto poveikio modelio rezultatai.

\section{Išvados}

Finansinès technologijos komerciniuose bankuose naudojamos jau ilgą laiką, tačiau jos nuolatos tobulëja ir pritaikomos naujos technologijos. Komerciniuose bankuose naudojama tokios finanisnès technologijos: elektroninè bankininkystè, bankomatai, debetinès ir kreditinès kortelès, mobiliosios banko programèlès, elektroniniai mokejjimai, centralizuotas duomenų valdymas, SWIFT mokèjimų sistema, nuotolinès konsultacijos ar periodiniai mokejjimai. Visos šios naudojamos finansinès technologijos komerciniuose bankuose suteikia bankams pranašumų rinkoje siekiant pagerinti klientų patirtis, palengvinti naudojimąsi bankų paslaugomis, pagreitinti procesus ar suatupyti darbo išteklius. Komerciniai bankai vis daugiau paslaugų gali pasiūlyti savitarnos zonose, o tai sutaupo darbuotojų darbo laiką, tačiau kiekvienos finansinès technologijos diegimas komerciniams bankams yra papildomi kaštai siekiant išlikti rinkoje ir neatsilikti nuo konkurentų. Tai investicija, kuri kartais daugiau naudos suteikia klientams, tačiau tai nepadidina banko pelningumo, kuris dažniausiai matuojamas dviem pagrindiniais rodikliais: ROA ir ROE rodikliai.

Atliekant tyrimą buvo naudojama Lietuvoje veikiančių trijų komercinių bankų rezultatai nuo $2014 \mathrm{~m}$. iki 2018 m. ịvertinta mokejjimo kortelių skaičiaus, bankomatų skaičiaus, mokejjimo kortelių skaitytuvų skaičiaus ir elektroninès bankininkystès vartotojų skaičiaus įtaka ROA rodikliui ir ROE rodikliui. Tyrimas buvo atliktas dviem panelinių duomenų analizavimo modeliais: fiksuoto poveikio ir pastovios konstantos modeliai. Pastovios konstantos modelio rezultatai vertinant modelio reikšmingumą ir patikimumą gauti geresni nei kito modelio. Vertinant Fišerio kriterijų modelio rezultatai yra reikšmingi, o jų patikimumas apie $50 \%$, tačiau vertinant kiekvieno kintamojo rezultatus Stjudento testo rezultatai neparodè nei vieno reikšmingo kintamojo. Atlikus fiksuoto poveikio modelio skaičiavimus, gauti rezultatai yra statistiškai nereikšmigi ir mažai patikimi - $29 \%$.

Atlikus tyrimą, nei vienu modeliu nebuvo gauti statistiškai reikšmingi rezultatai, patvirtinantys finansinių technologijų daromą ịtaką komercinių bankų pelningumo rodikliams. Modeliuose vertinant gautus koeficientus, nereikšmingą teigiamą ịtaką komercinių bankų pelningumo rodikliams daro bankomatų naudojimas. Remiantis gautais tyrimo rezultatais, visos hipotezès yra atmetamos,kadangi gauti rezultatai nèra statistiškai reikšmingi.

Apibendrinus gautus tyrimo rezultatus, finansinès technologijos naudojamos komerciniuose bankuose, nedaro reikšmingos įtakos banko pelningumui. Tačiau svarbu atkreipti dėmesį, kad siekiant konkuruoti finansų rinkose ir išlaikyti savo klientus komerciniai bankai diegia finansines technologijas ir investuoja šioje srityje siekdami ne tik padidinti pelno rodiklius, tačiau išsilaikyti finansų rinkoje.

\section{Literatūra}

Abate, T. W., \& Mesfin, E. A. (2019). Factors Affecting Profitability of Insurance Companies in Ethiopia. International Journal of Research and Analytical Reviews, 6(1), 881-891.

Abbas, F., Butt, S., Masood, O., \& Javaria, K. (2019). The effect of bank capital buffer on bank risk and net interest margin: Evidence from the US. Global Journal of Social Sciences Studies, 5(2), $72-87$. https://doi.org/10.20448/807.5.2.72.87

Abraham, R., Harris, J., \& Auerbach, J. (2017). Earnings yield as a predictor of return on assets, return on equity, economic value added and the equity multiplier. Modern Economy, 8(1), 10-24. https://doi.org/10.4236/me.2017.81002

Akhisar, İ., Tunay, K. B., \& Tunay, N. (2015). The effects of innovations on bank performance: The case of electronic banking services. Procedia - Social and Behavioral Sciences, 195, 369-375. https://doi.org/10.1016/j.sbspro.2015.06.336

Alt, R., Beck, R., \& Smits, M. T. (2018). FinTech and the transformation of the financial industry. Electronic Markets, 28(3), 235-243. https://doi.org/10.1007/s12525-018-0310-9

Bhagyashree, D. (2018). Digitisation in banking. In Conference of Digital Economy and its Impact on Business and Industry, (ICDEBI-2018) (pp. 80-85).

Cheng, G., \& Mevis, D. (2019). What happened to profitability? Shocks, challenges and perspectives for euro area banks. The European Journal of Finance, 25(1), 54-78. https://doi.org/10.1080/1351847X.2018.1470994

Ciciretti, R., Hasan, I., \& Zazzara, C. (2009). Do internet activities add value? Evidence from the traditional banks. Journal of Financial Services Research, 35(1), 81-98. https://doi.org/10.1007/s10693-008-0039-2

Dhar, V., \& Stein, R. M. (2017). Economic and business dimensions: FinTech platforms and strategy. Communications of the ACM, 60(10), 32-35. https://doi.org/10.1145/3132726

Djalilov, K., \& Piesse, J. (2016). Determinants of bank profitability in transition countries: What matters most? Research in International Business and Finance, 38, 69-82. https://doi.org/10.1016/j.ribaf.2016.03.015

Drasch, B. J., Schweizer, A., \& Urbach, N. (2018). Integrating the 'Troublemakers': A taxonomy for cooperation between banks and fintechs. Journal of Economics and Business, 100, 26-42. https://doi.org/10.1016/j.jeconbus.2018.04.002

Olalere, O. E., Wan Bin Omar, W. A., \& Kamil, S. (2017). Bank specific and macroeconomic determinants of commercial bank profitability: Empirical evidence from Nigeria. International Journal of Finance \& Banking Studies, 6(1), 25-38. https://doi.org/10.20525/ijfbs.v6i1.627 
Fuster, A., Plosser, M., Schnabl, P., \& Vickery, J. (2019). The role of technology in mortgage lending. The Review of Financial Studies, 32(5), 1854-1899. https://doi.org/10.1093/rfs/hhz018

Gai, K., Qiu, M., \& Sun, X. (2018). A survey on FinTech. Journal of Network and Computer Applications, 103, $262-273$. https://doi.org/10.1016/j.jnca.2017.10.011

Ghebregiorgis, F., \& Atewebrhan, A. (2016). Measurement of bank profitability, risk and efficiency: The case of the Commercial Bank of Eritrea and Housing and Commerce Bank of Eritrea. African Journal of Business Management, $10(22), 554-562$.

Gupta, S. D., Raychaudhuri, A., \& Haldar, S. K. (2018). Information technology and profitability: Evidence from Indian banking sector. International Journal of Emerging Markets, 13(5), 1070-1087. https://doi.org/10.1108/IJoEM-06-2017-0211

Gupta, S., \& Yadav, A. (2017). The impact of electronic banking and information technology on the employees of banking sector. Management and Labour Studies, 42(4), 379-387. https://doi.org/10.1177/2393957517736457

Islam, S., Kabir, M. R., Dovash, R. H., Nafee, S. E., \& Saha, S. (2019). Impact of online banking adoption on bank's profitability: Evidence from Bangladesh. European Journal of Business and Management Research, 4(3), 1-4. https://doi.org/10.24018/ejbmr.2019.4.3.38

Javed, M. A., \& Basheer, M. F. (2017). Impact of external factors on bank profitability. EPRA International Journal of Research and Development, 2(5), 1-11.

Joshi, D., \& Parihar, S. (2017). Digitalization \& customer perception towards the banking services. Aweshkar Research Journal, 23(2), 133-141.

Ky, S., Rugemintwari, C., \& Sauviat, A. (2019). Is Fintech good for bank performance? The case of mobile money in the East African Community. SSRN Electronic Journal, 1-38. https://doi.org/10.2139/ssrn.3401930

Li, D., Qian, J., \& Su, L. (2016). Panel data models with interactive fixed effects and multiple structural breaks. Journal of the American Statistical Association, 111(516), 1804-1819. https://doi.org/10.1080/01621459.2015.1119696

Marozva, G. (2015). Liquidity and bank performance. International Business \& Economics Research Journal (IBER), 14(3), 453. https://doi.org/10.19030/iber.v14i3.9218

Nuhiu, A., Hoti, A., \& Bektashi, M. (2017). Determinants of commercial banks profitability through analysis of financial performance indicators: evidence from Kosovo. Business: Theory and Practice, 18(1), 160-170. https://doi.org/10.3846/btp.2017.017

Petria, N., Capraru, B., \& Ihnatov, I. (2015). Determinants of banks' profitability: Evidence from EU 27 banking systems. Procedia Economics and Finance, 20, 518-524. https://doi.org/10.1016/S2212-5671(15)00104-5

Phan, D. H. B., Narayan, P. K., Rahman, R. E., \& Hutabarat, A. R. (2019). Do financial technology firms influence bank performance? Pacific-Basin Finance Journal, 101210. https://doi.org/10.1016/j.pacfin.2019.101210

Pindado, J., \& Requejo, I. (2015). Panel data: a methodology for model specification and testing. In Wiley Encyclopedia of Management (pp. 1-8). John Wiley \& Sons, Ltd. https://doi.org/10.1002/9781118785317.weom040013

Puschmann, T. (2017). Fintech. Business \& Information Systems Engineering, 59(1), 69-76. https://doi.org/10.1007/s12599-017-0464-6

Ramadhanti, C., Marlina, M., \& Hidayati, S. (2019). The effect capital adequacy, liquidity and credit risk to profitability of commercial banks. Journal of Economics, Business, and Government Challenges, 2(1), 71-78. https://doi.org/10.33005/ebgc.v2i1.66

Rega, F. G. (2017). The bank of the future, the future of banking - an empirical analysis of European banks. SSRN Electronic Journal. https://doi.org/10.2139/ssrn.3071742

Rehman, Z. ur, Khan, S. A., Khan, A., \& Rahman, A. (2018). Internal factors, external factors and bank profitability. Sarhad Journal of Management Sciences, 4(2), 246-259. https://doi.org/10.31529/sjms.2018.4.2.9

Saiful, S., \& Ayu, D. P. (2019). Risks management and bank performance: The empirical evidences from Indonesian conventional and Islamic banks. International Journal of Economics and Financial Issues, 9(4), 90-94. https://doi.org/10.32479/ijefi.8078

Saksonova, S., \& Kuzmina-Merlino, I. (2017). Fintech as financial innovation - the possibilities and problems of implementation. European Research Studies Journal, 20(3A), 961-973. https://doi.org/10.35808/ersj/757

Salhuteru, F., \& Wattimena, F. (2015). Bank Performance with CAMELS Ratios towards earnings management practices in State Banks and Private Banks. Advances in Social Sciences Research Journal, 2(4), 301-314. https://doi.org/10.14738/assrj.24.940

Scott, S. V., Van Reenen, J., \& Zachariadis, M. (2017). The long-term effect of digital innovation on bank performance: An empirical study of SWIFT adoption in financial services. Research Policy, 46(5), 984-1004. https://doi.org/10.1016/j.respol.2017.03.010

Skvarciany, V., \& Simanavičiūtè, J. (2018). Bank profitability analysis and forecasting: Lithuania case. Trends Economics and Management, 12(32), 101. https://doi.org/10.13164/trends.2018.32.101

Suppia, N. M. I., \& Arshad, N. C. (2019). Bank specific characteristics and profitability of Islamic and conventional banks in Malaysia, 4(1), 39-53.

Thakor, A. V. (2020). Fintech and banking: What do we know? Journal of Financial Intermediation, 41, 100833. https://doi.org/10.1016/j.jfi.2019.100833

Tran, V. T., Lin, C.-T., \& Nguyen, H. (2016). Liquidity creation, regulatory capital, and bank profitability. International Review of Financial Analysis, 48, 98-109. https://doi.org/10.1016/j.irfa.2016.09.010 


\section{RESEARCH ON IMPACT OF FINANCIAL TECHNOLOGIES ON COMMERCIAL BANKS PROFITABILITY RATIOS}

\section{Indrè LAPINSKAITĖ, Reda KVEDARYTĖ}

Abstract. The aim of this study is to evaluate impact of financial technologies on commercial banks profitability. The research analyzes scientific literature, distinguishes the research methods used, and performs linear regression analysis to evaluate the impact. The research analyzes financial technologies used by commercial banks operating in Lithuania (payment cards, ATMs, EFTPOS, electronic banking) and return on assets (ROA) and return on equity (ROE) ratios. The study rejects the hypotheses that financial technologies have an impact on commercial banks "profitability ratios, as the results of the research did not show significant impact of financial technologies on commercial banks" profitability ratios. The results of the study may alert commercial banks to the return on investment of financial technology. However, it is important to note the limitations as the results of this study are based only on commercial banks operating in Lithuania and the small sample size may lead to inaccurate results.

Keywords: commercial bank, financial technology, impact, return on assets (ROA), return on equity (ROE), profitability. 